Check for updates

London

Cite this as: BMJ2020;370:m3702 http://dx.doi.org/10.1136/bmj.m3702 Published: 21 September 2020

\section{Covid-19: Experts divide into two camps of action-shielding versus blanket policies}

\author{
Jacqui Wise
}

Two open letters sent to the UK's four chief medical officers signal the polarisation of opinion among medical professionals over how the government should tackle the emerging "second wave" of covid-19.

One group of doctors and academics is calling for segmentation and shielding of the most vulnerable groups of people rather than local or national lockdown measures. However, another group says that the government should continue efforts to suppress the virus across the entire population.

Sunetra Gupta, professor of theoretical epidemiology at Oxford University, Carl Heneghan, director of the Centre for Evidence Based Medicine at Oxford, Karol Sikora, a consultant oncologist at the University of Buckingham, and 30 others are calling on the government to take a more targeted approach rather than blanket policy interventions. ${ }^{1}$ They argue that because $89 \%$ of covid deaths are in the over 65 group and are also concentrated in people with pre-existing medical conditions these are the groups at which interventions should be targeted. Given the high proportion of covid deaths in care homes, these should be a priority, they add.

"This large variation in risk by age and health status suggests that the harm caused by uniform policies (that apply to all persons) will outweigh the benefits," the group's letter says. It adds that blanket policy interventions can have adverse effects on physical and mental health as well as social and economic impacts. The effect on cancer treatment is especially acute, it says, with people delaying or missing screenings, tests, or treatments.

Meanwhile a letter from Trisha Greenhalgh, chair of primary care health sciences at Oxford University and signed by 22 others, argues against pursuing a "herd immunity" approach. ${ }^{2}$ They say that although the incidence and outcomes of covid-19 vary across different groups, deaths have occurred in all age, sex, and ethnic groups and among people with no pre-existing medical conditions. They also point out that "long covid," in which symptoms extend for weeks or months after infection, is a debilitating disease affecting tens of thousands of people in the UK and can occur in previously young and healthy individuals.

This letter, which has been signed by Harry Burns, former chief medical officer for Scotland, and Martin McKee, professor of European Public Health at the London School of Hygiene and Tropical Medicine, among others, also argues that to divide a particular group of vulnerable people from those less vulnerable is practically impossible, particularly in disadvantaged groups, who may live in cramped housing and multi-generational households. They say that a goal of herd immunity rests on the unproved assumption that reinfection will not occur and that no examples of a segmentation and shielding policy having worked exist in any country.

The letter, published on BMJ Opinion, says that the country may have to move flexibly between levels of restriction rather than either full lockdown or release, depending on how well the virus is controlled. They also say that measures that would help control the virus while also promoting economic recovery include making face coverings mandatory in crowded indoor spaces, improving ventilation in schools and workplaces, continuing to require social distancing, and discouraging large indoor gatherings.

They add that it is important to restore routine medical appointments through a combination of remote appointments together with face-to-face appointments with appropriate personal protective equipment.

\section{Sikora K. Twitter. 21 Sep 2020. https://twitter.com/ProfKarolSikora/sta- tus/1307972101463212032/photo/3. \\ 2 Alwan NA, Bogaert D, Burns H, et al. Covid-19: an open letter to the UK'S chief medical officers. BMJ Opinion. 21 Sep 2020. \\ https://blogs.bmj.com/bmj/2020/09/21/covid-19-an-open-letter-to-the- uks-chief-medical-officers.}

This article is made freely available for use in accordance with BMJ's website terms and conditions for the duration of the covid-19 pandemic or until otherwise determined by BMJ. You may use, download and print the article for any lawful, non-commercial purpose (including text and data mining) provided that all copyright notices and trade marks are retained. 